\title{
Diagnosis of Statin-Induced Necrotizing Myopathy: Contribution of Anti-HMGCR Antibodies
}

\author{
Diagnóstico da Miopatia Necrotizante Induzida por Estatinas: \\ Contribuição dos Anticorpos Anti-HMGCR
}

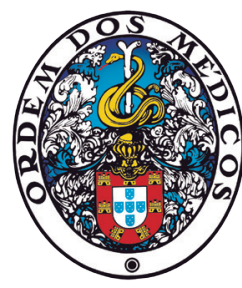

\author{
Cláudia FIDALGO $\rrbracket^{1}$, Alice MENDES ${ }^{1}$, Rosário CUNHA ${ }^{1}$, Fernando RODRIGUES ${ }^{1}$ \\ Acta Med Port 2022 Jul-Aug;35(7-8):584-587 - https://doi.org/10.20344/amp.16181
}

\section{ABSTRACT}

Over the last few years, several cases of statin-induced necrotizing myopathy have been described. This myopathy is characterized by the necrosis of muscle fibers and the presence of anti-3-hydroxy-3-methylglutaryl-coenzyme A reductase (anti-HMGCR) antibodies. Although the diagnosis of myopathies relies on muscle biopsy, which is considered the gold-standard, the search for autoantibodies has proved to be an essential contribution to the diagnosis of immune-mediated myopathies. The detection of anti-HMGCR antibodies in the patient's serum can be performed by enzyme immunoassays, and more recently, by imunofluorescence. As for the latter, the detection of anti-HMGCR antibodies is performed on tissue sections by indirect immunofluorescence and is characterized by a typical fluorescence pattern called "HMGCR Associated Liver IFL Pattern". The authors present two case reports that show the importance of diagnosing statin-induced necrotizing myopathy as quickly as possible and the contribution of anti-HMGCR antibody detection for the diagnosis.

Keywords: Autoimmune Diseases/chemically induced; Hydroxymethylglutaryl CoA Reductases; Hydroxymethylglutaryl-CoA Reductase Inhibitors/adverse effects; Muscular Diseases/chemically induced

\section{RESUMO}

Nos últimos anos foram descritos vários casos de miopatia necrotizante induzida por estatinas. Esta miopatia caracteriza-se por necrose das fibras musculares e pela presença de anticorpos anti-3-hidroxi-3-metilglutaril-coenzima A redutase (anti-HMGCR). Apesar do diagnóstico das miopatias depender da biópsia muscular, considerada o gold-standard, a pesquisa dos auto-anticorpos tem-se revelado uma contribuição fundamental para o diagnóstico das miopatias imuno-mediadas. A pesquisa dos anticorpos anti-HMGCR no soro do doente pode ser efetuada por recurso a imunoensaios enzimáticos e mais recentemente foi descrita a possibilidade da sua deteção por imunofluorescência. Neste caso, a pesquisa de anticorpos anti-HMGCR é efetuada em seções de tecido, por imunofluorescência indireta e caracteriza-se pela deteção de um padrão de fluorescência típico denominado "HMGCR Associated Liver IFL Pattern". Os autores apresentam dois casos-clínicos que evidenciam não só a importância de diagnosticar o mais rapidamente possível a miopatia necrotizante induzida por estatinas como também a contribuição da deteção de anticorpos anti-HMGCR para o diagnóstico desta miopatia.

Palavras-chave: Doenças Autoimunes/induzidas quimicamente; Doenças Musculares/induzidas quimicamente; Hidroximetilglutaril-CoA Redutases; Inibidores de Hidroximetilglutaril-CoA Redutases/efeitos adversos

\section{INTRODUCTION}

Immune mediated necrotizing myopathy (IMNM) is characterized by progressive and disabling proximal muscle weakness, high serum levels of creatine kinase (CK) and the presence of necrotic fibers with minimal inflammatory cell infiltrate on muscle biopsy. ${ }^{1,2}$ The European Neuromuscular Centre has recognized three serologically different subtypes of IMNM: autoantibody negative, anti-signal recognition particle and anti-hydroxy-3-methylglutaryl-coenzyme A reductase (anti-HMGCR) myopathy. Recently, several cases of anti-HMGCR myopathy associated with statins exposure were described, which raised the profile of this IMNM and the need to diagnose it as soon as possible.

Statins competitively inhibit HMGCR and have a well-established role in the secondary prevention of cardiovascular events. ${ }^{3}$ However, clinical data suggests that the adverse reactions of statins may affect at least $30 \%$ of patients. ${ }^{4}$ Among the several possible adverse reactions, statin-associated myopathy is the most common, with anti-HMGCR IMNM being the most severe subtype. ${ }^{5}$ The exact incidence of statin associated myopathy is not known. However, recent studies reported that the incidence may vary from 15\% to $72 \%$ depending on age, geographic location and eating habits as anti-HMGCR could be associated with both the medicine and natural statins occurring in food such as red yeast rice. ${ }^{6}$

The diagnosis of myopathy relies on muscle biopsy, which is considered the gold-standard. Nevertheless, in IMNM, the screening of serum antibodies is changing the diagnostic algorithm. Serology studies are now considered as important as histological studies, with the detection of anti-HMGCR antibodies considered the hallmark in the diagnosis of anti-HMGCR IMNM.

During a 24-hour period, the detection of antibodies could be achieved by immunoassays such as immunoblot and enzyme linked immunosorbent assay. In 2016, Alvarado-Cardenas et al used indirect immunofluorescence in rat tissue sections to evaluate serum antibodies of IMNM patients and identified a new specific pattern which was

\footnotetext{
1. Serviço de Patologia Clínica. Centro Hospitalar e Universitário de Coimbra. Coimbra. Portugal.

$\triangle$ Autor correspondente: Cláudia Fidalgo.11413@chuc.min-saude.pt

Recebido/Received: 13/03/2021 - Aceite/Accepted: 06/07/2021 - Publicado Online/Published Online: 30/10/2021 - Publicado/Published: 01/07/2022 Copyright $\odot$ Ordem dos Médicos 2022
} 
called HMGCR Associated Liver IFL Pattern (HALIP). ${ }^{7}$ This pattern is characterized by the presence of stained hepatocytes (no more than 10\%) with a centro-lobular distribution. Moreover, the staining was limited to the cytoplasm and spared the nuclei. ${ }^{7}$

In order to emphasize that anti-HMGCR IMNM may present a rapid and fatal course, as well as to highlight the role of antibody detection in the diagnosis of this myopathy, we present two patients with anti-HMGCR statin-induced IMNM.

\section{CASE REPORTS}

Patient 1 was a 72-year-old man admitted to the emergency department due to a 4-week history of myalgia and decrease of muscle strength in the lower limbs, without other neuromuscular symptoms. One month before the onset of symptoms the patient started taking pitavastatin 4 $\mathrm{mg}$, in addition to atorvastatin $40 \mathrm{mg}$. The patient had been taking atorvastatin for a few months but since he was not achieving the therapeutic goal, atorvastatin was switched to pitavastatin. Due to a misunderstanding, the patient kept taking both statins. The patient had a clinical history of dyslipidemia, arterial hypertension, and type 2 diabetes mellitus. As for family history, the patient's daughter had a multiminicore congenital myopathy. At the time of the daughter's myopathy diagnosis, the patient did not undergo genetic testing since he presented normal CK values. On admission, he was found to have CK levels of $9764 \mathrm{U} / \mathrm{L}$ (reference range (rf) < $171 \mathrm{U} / \mathrm{L}$ ), lactic dehydrogenase (LDH) of 1046 $\mathrm{U} / \mathrm{L}(\mathrm{rf}<248 \mathrm{U} / \mathrm{L}$ ), aspartate transaminase (AST) of 376 $\mathrm{U} / \mathrm{L}$ (rf $<35 \mathrm{U} / \mathrm{L}$ ), alanine transaminase (ALT) of $444 \mathrm{U} / \mathrm{L}$ (rf $45 \mathrm{U} / \mathrm{L}$ ) and increased inflammatory parameters, (Table 1).

Table 1 - Summary of patient characteristics and diagnostic test results

\begin{tabular}{|c|c|c|}
\hline & Patient 1 & Patient 2 \\
\hline \multicolumn{3}{|l|}{ Patient's characteristics } \\
\hline Age & 72 & 59 \\
\hline Sex & Male & Male \\
\hline Symptoms & $\begin{array}{l}\text { Myalgia and decrease of muscle strength } \\
\text { in the lower limbs }\end{array}$ & $\begin{array}{l}\text { Decrease of muscle strength and episode of } \\
\text { rhabdomyolysis }\end{array}$ \\
\hline Statin & Pitavastatin $4 \mathrm{mg}+$ Atorvastatin $40 \mathrm{mg}^{1}$ & Atorvastatin $20 \mathrm{mg}$ \\
\hline Medical history & $\begin{array}{l}\text { Dyslipidemia, arterial hypertension, type } \\
2 \text { diabetes mellitus, benign prostatic } \\
\text { hyperplasia }\end{array}$ & Dyslipidemia, knee osteoarthritis \\
\hline Family history & $\begin{array}{l}\text { Daughter with multiminicore congenital } \\
\text { myopathy }\end{array}$ & Irrelevant \\
\hline \multicolumn{3}{|l|}{ Blood tests } \\
\hline Leucocytes $^{2}$ & $15.2 \times 10^{9} / \mathrm{L}$ & $9.5 \times 10^{9} / \mathrm{L}$ \\
\hline Neutrophils $^{2}$ & $14.14 \times 10^{9} / \mathrm{L}$ & $5.45 \times 10^{9} / \mathrm{L}$ \\
\hline $\mathbf{C K}^{2}$ & $9764 \mathrm{U} / \mathrm{L}$ & $8635 \mathrm{U} / \mathrm{L}$ \\
\hline $\mathrm{LDH}^{2}$ & $1046 \mathrm{U} / \mathrm{L}$ & $908 \mathrm{U} / \mathrm{L}$ \\
\hline $\mathrm{AST}^{2}$ & $376 \mathrm{U} / \mathrm{L}$ & $217 \mathrm{U} / \mathrm{L}$ \\
\hline $\mathrm{ALT}^{2}$ & $444 \mathrm{U} / \mathrm{L}$ & $196 \mathrm{U} / \mathrm{L}$ \\
\hline C-reactive protein (CRP) ${ }^{2}$ & $11.46 \mathrm{mg} / \mathrm{dL}$ & $0.49 \mathrm{mg} / \mathrm{dL}$ \\
\hline Anti-HMGCR antibodies ${ }^{3}$ & HMGCR antibodies detected & HMGCR antibodies detected \\
\hline $\begin{array}{l}\text { Other autoimmune myositis } \\
\text { autoantibodies }{ }^{4}\end{array}$ & Not detected & Not detected \\
\hline \multicolumn{3}{|l|}{ Other diagnostic tests } \\
\hline EMG & Acute signs of muscle fiber injury & Acute signs of muscle fiber injury \\
\hline Muscle biopsy & Extensive necrotic areas & Muscle cell necrosis \\
\hline \multicolumn{3}{|l|}{ Treatment and evolution } \\
\hline Treatment & Prednisolone and immunoglobulin & Prednisolone \\
\hline Evolution & Infectious complications that led to death & $\begin{array}{l}\text { Good; maintenance of low dose corticosteroid } \\
\text { therapy }\end{array}$ \\
\hline
\end{tabular}

${ }^{1}$ Due to misunderstanding the patient kept taking atorvastatin concomitantly with pitavastatin.

${ }^{2}$ Levels at admission; Leucocytes reference range (rf) $4.0-10.0 \times 10^{9}$; neutrophils if $2.0-7.0 \times 10^{9} ; \mathrm{CK}$ rf < $171 \mathrm{U} / \mathrm{L} ;$ LDH rf < $248 \mathrm{U} / \mathrm{L} ; \mathrm{AST}$ rf < $35 \mathrm{U} / \mathrm{L} ; \mathrm{ALT}$ rf $45 \mathrm{U} / \mathrm{L} ; \mathrm{CRP}$ rf < 0.50 $\mathrm{mg} / \mathrm{dL}$.

${ }^{3} \mathrm{IgG}$ antibodies detection by immunodot assay. Detection of IgG antibodies against Jo-1, PL-7, PL-12, EJ, SRP, Mi-2, MDA-5, TIF1Y, HMGCR, SSA/Ro-52, SAE1/2 and NXP-2. BlueDot Myositis ${ }^{12} \lg G-D^{-t^{\circ}}{ }^{\circledR}$.

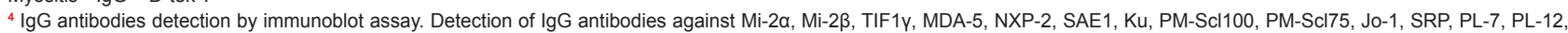
EJ, OJ and Ro-52 antigens. EUROLINE Autoimmune Inflamatory Myopaties 16 Ag - EUROIMMUN ${ }^{\circledR}$. 
The patient was admitted for diagnostic investigation. Electromyography (EMG) revealed acute signs of muscle fiber injury and the muscle biopsy showed extensive necrotic areas. The study of specific myositis antibodies revealed the presence of anti-HMGCR antibodies, and immunofluorescence revealed the presence of HALIP (Figs. 1A, 2A), ten days after hospital admission. The patient started treatment with methylprednisolone with a slight improvement in symptoms and in analytical parameters. Due to clinical worsening, methylprednisolone was replaced by prednisolone and 31 days after hospital admission he started treatment with immunoglobulin. Nevertheless, 39 days after hospital admission, the patient died due to infectious complications.

Patient 2 was a 59-year-old male outpatient admitted for diagnostic investigation after an episode of rhabdomyolysis with increased levels of CK (8635U/L), LDH (908 U/L), AST (217 U/L) and ALT (196 U/L); normal inflammatory parameters; and complaints of muscle strength weakness, (Table 1). He had been taking atorvastatin $20 \mathrm{mg}$ in the previous month and had a medical history of dyslipidemia and knee osteoarthritis. The EMG revealed acute muscle fiber injury, and the muscle biopsy showed muscle cell necrosis. The diagnostic investigation of specific myositis antibodies revealed the presence of anti-HMGCR antibodies and immunofluorescence revealed the presence of HALIP (Figs. 1B, $2 \mathrm{~B})$. The patient started treatment with prednisolone one year after the first appointment, with clinical and analytical improvement.

In both patients, the presence of anti-HMGCR antibodies was evaluated by immunoblot (D-tek ${ }^{\circledR}$ ) followed by indirect immunofluorescence in rat triple tissue sections (EUROIM-
$\mathrm{MUN}^{\circledR}$ ). A pattern of stained hepatocytes with centrilobulardistribution, confined to the cell's cytoplasm, similar to the one described by Alvarado-Cardenas et al, ${ }^{7}$ was observed in both patient samples (Fig. 2) but not in the internal control sample. This pattern was observed in less than $10 \%$ of the stained hepatocytes.

\section{DISCUSSION}

These case reports highlighted the role of serological screening whenever the patients are taking statins and present complaints suggestive of myopathy. Although the detection of serum autoantibodies is not the gold-standard in the diagnosis of myopathies, it has several advantages over muscle biopsy such as being less invasive, faster (muscle biopsy has a turnaround time of approximately one week), easier to perform, and most immunology laboratories already use the lab-testing methodologies. Since immunofluorescence is less expensive and faster compared to immunoblot, and HMGCR is highly expressed in liver tissue, ${ }^{7}$ immunofluorescence seems to be adequate to screen for the presence of HMGCR antibodies. Both case reports showed that the detection of HALIP by immunofluorescence is a useful test to screen for anti-HMGCR myopathy in statinexposed patients. Since anti-HMGCR antibodies are highly associated with statin-induced IMNM,${ }^{1}$ their presence is a warning that statin dose should be evaluated and eventually be discontinued. It is also important to emphasize that in a patient taking statins and complaining of myalgia one of the first procedures is to evaluate serum CK level. If CK levels rise to more than 10 times the upper limit, the risk and benefit of statin withdrawal should be assessed. ${ }^{8}$

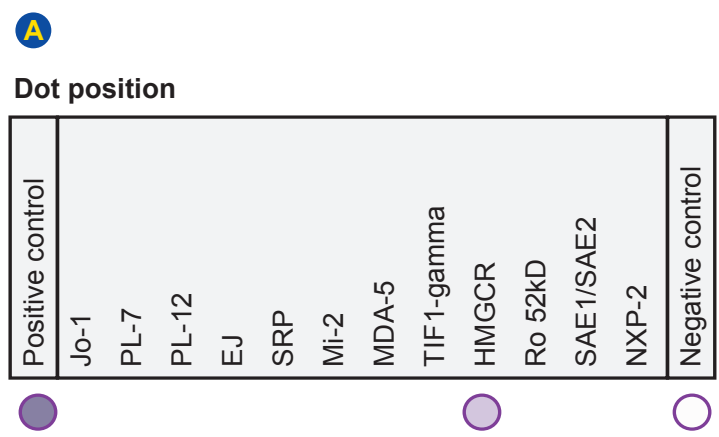

\section{B}

Dot position

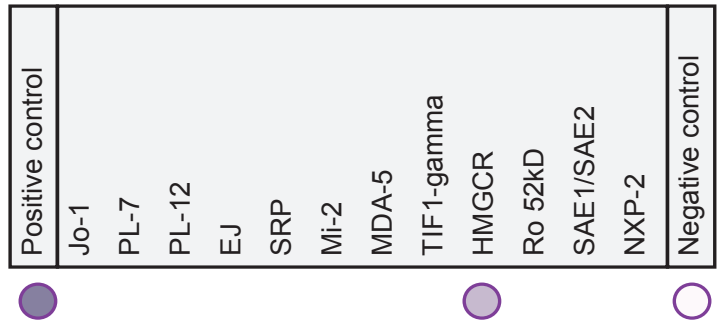

MYO12D

Figure 1 - Anti-HMGCR antibodies detected by immunodot assay. BlueDot Myositis12 lgG - D-tek ${ }^{\circledR}$ (A) Patient 1; (B) Patient 2.
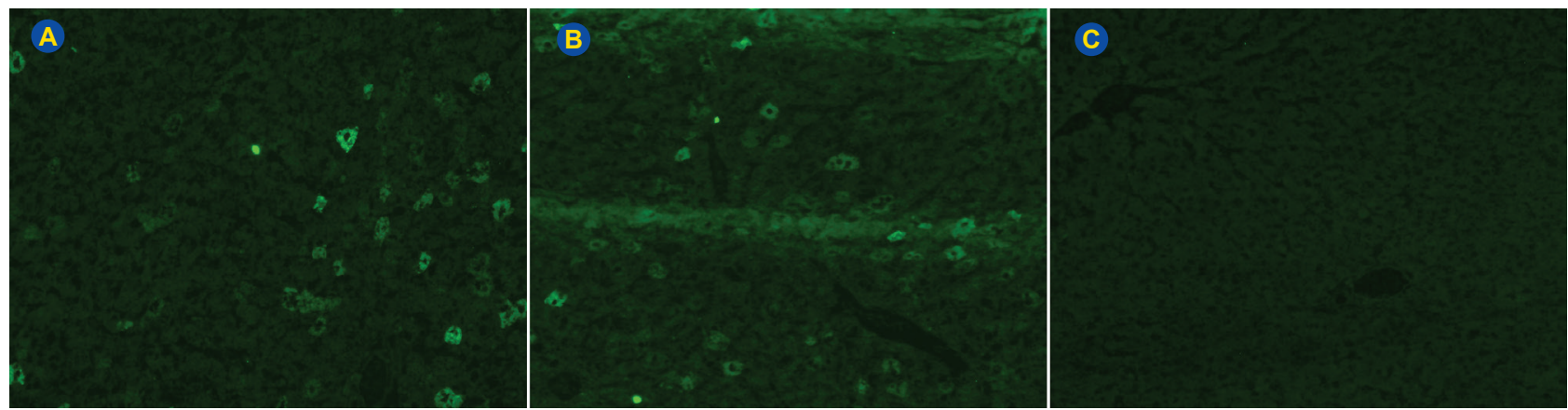

Figure 2 - HALIP pattern in rat liver sections. Indirect immunofluorescence using triple rat tissue. No fluorescence was observed in kidney and stomach sections. (A) Patient 1; (B) Patient 2; (C) Internal control sample.

Images captured by EUROPattern (EUROIMMUN ${ }^{\circledR}$ ). 


\section{CONCLUSION}

Statin-induced IMNM is an autoimmune disease associated with the presence of anti-HMGCR antibodies that may present with a rapid, aggressive and fatal clinical course if not rapidly diagnosed. The clinical course of this myopathy seems to be associated with the statin dose, which is in agreement with previous studies. ${ }^{6,9}$ The detection of antiHMGCR antibodies may contribute to the early diagnosis of this IMNM and to the development of a successful therapeutic strategy. ${ }^{7}$

\section{AUTHORS CONTRIBUTION}

CF: Case description and discussion.

AM, RC, FR: Critical review of the work.

\section{PROTECTION OF HUMANS AND ANIMALS}

The authors declare that the procedures were followed according to the regulations established by the Clinical Re-

\section{REFERENCES}

1. Mohassel P, Mammen AL. Anti-HMGCR myopathy. J Neuromuscul Dis. 2018:5:11-20.

2. Baucells A, Martínez MA, Alvarado-Cardenas M, Mariscal A, MartinezMartinez L, Juárez $C$, et al. Anti-HMGCR specificity of HALIP: a confirmatory study. J Immunol Res. 2020;2020:1-4.

3. Liu Y, Lv X, Xie N, Fang Z, Ren W, Gong Y, et al. Time trends analysis of statin prescription prevalence, therapy initiation, dose intensity, and utilization from the hospital information system of Jinshan Hospital, Shanghai (2012-2018). BMC Cardiovasc Disord. 2020;20:1-13.

4. Ward NC, Watts GF, Eckel RH. Statin toxicity: mechanistic insights and clinical implications. Circ Res. 2019;124:328-50.

5. Baptista B, Tavares J, Marto N, Horta A, Roque R, Mascarenhas V. Miopatia imunomediada por anticorpos anti-HMGCR: revisão da literatura com base num caso clínico. Med Interna. 2019;26:314-9.

6. Anquetil C, Boyer O, Wesner N, Benveniste O, Allenbach Y. Myositis- search and Ethics Committee and to the Helsinki Declaration of the World Medical Association updated in 2013.

\section{DATA CONFIDENTIALITY}

The authors declare having followed the protocols in use at their working center regarding patients' data publication.

\section{INFORMED CONSENT}

Obtained.

\section{COMPETING INTERESTS}

The authors declare that there are no competing interests.

\section{FUNDING SOURCES}

The authors declare that there were no external sources of funding for the writing of this article.

specific autoantibodies, a cornerstone in immune-mediated necrotizing myopathy. Autoimmun Rev. 2019;18:223-30.

7. Alvarado-Cardenas $M$, Marin-Sánchez A, Martínez MA, MartínezMartínez L, Pinal-Fernandez I, Labrador-Horrillo M, et al. Statinassociated autoimmune myopathy: a distinct new IFL pattern can increase the rate of HMGCR antibody detection by clinical laboratories. Autoimmun Rev. 2016;15:1161-6.

8. Selva-O'Callaghan A, Alvarado-Cardenas M, Pinal-Fernández I, TralleroAraguás E, Milisenda J, Martínez M, et al. Statin-induced myalgia and myositis: an update on pathogenesis and clinical recommendations. Expert Rev Clin Immunol. 2018;14:215-24.

9. Moita C, Mendonça A, Leite R, de Vasconcellos A. Statin-associated necrotizing myopathy: a rare etiology. Rev Port Clínica Geral. 2020;36:503-6. 